\title{
Clinical Trial Medical Device Investigators Agreement
}

National Cancer Institute

\section{Source}

National Cancer Institute. Clinical Trial Medical Device Investigators Agreement. NCI

Thesaurus. Code C125432.

Non-financial agreement for medical devices between a sponsor and a clinical trial investigator documenting various responsibilities. 